\title{
Changes in the Plasma Testosterone Level and Testicular Superoxide Dismutase Activity of 5 Azoospermic Beagles after GnRH Analogue Injections
}

\author{
Eiichi KAWAKAMI ${ }^{1)}$, Daiki KURODA ${ }^{1)}$, Tatsuya HORI ${ }^{1)}$ and Toshihiko TSUTSUI ${ }^{1)}$ \\ ${ }^{1)}$ Department of Reproduction, Nippon Veterinary and Life Science University, 1-7-1 Kyonan-cho, Musashino-shi, Tokyo 180-8602, \\ Japan
}

(Received 6 September 2006/Accepted 23 January 2007)

ABSTRACT. The peripheral blood plasma testosterone (T) levels and superoxide dismutase (SOD) activity were measured in 5 azoospermic $(\mathrm{AZ}-)$ beagles. The mean values in the AZ-dogs were significantly lower than in 7 control beagles $(\mathrm{P}<0.001)$. Subcutaneous injections of $1 \mu \mathrm{g} / \mathrm{kg} \mathrm{GnRH}$ analogue three times weekly in the AZ-dogs induced significant increases in mean T level and SOD activity $(\mathrm{P}<0.05)$ and improvement in spermatogenesis. Thus, spermatogenic function in the dog appears to be maintained by T and normal SOD activity in the testis.

KEY WORDS: azoospermia, canine, SOD.

J. Vet. Med. Sci. 69(5): 561-562, 2007

Production of reactive oxygen species (ROS) by testicular tissue [13, 18] and sperm [1, 17] has been reported in male animals. Oxidative stress caused by elevated ROS concentrations induces spermatogenic dysfunction [9] and poor semen quality [10], and high ROS concentrations in the seminal plasma of dogs also causes low sperm motility [15]. Superoxide dismutase (SOD) is known to be the most important antioxidant enzyme in seminal plasma [5], and SOD activity has been detected in canine seminal plasma [2]. Leydig [8] and Sertoli cells [11] have been reported to produce SOD in the testis. Low SOD activity in seminal plasma causes infertility in humans [14]. Although the cause of spermatogenic arrest in the dog is not well understood [4], the authors have reported that GnRH analogue (A) injection transiently improved the semen quality of some dogs with poor testosterone (T) secretory function in the testes and spermatogenic dysfunction [7]. In the present study the plasma $T$ levels and testicular SOD activities of azoospermic (AZ-) dogs were measured after GnRH-A injections in order to investigate the cause of spermatogenic dysfunction and the interaction between $\mathrm{T}$ secretory function and SOD activity in the testes.

Five AZ-beagles (4-7 years old) cared for at our university were used in this study. The 5 dogs had previously been diagnosed with azoospermia based on examinations of ejaculated semen collected by digital manipulation at weekly intervals for 4 weeks. Seven beagles (3-6 years old) with normal semen quality (the total number of sperm was more than $300 \times 10^{6}$, more than $80 \%$ of sperm were actively motile, and less than $10 \%$ of sperm were abnormal) were used as controls.

The GnRH-A used in this study was GnRH ethylamide (D-Ser-(tBu)-des-gly-NH $\mathrm{NH}_{2}$; Buserelin, Hoechst Inc., Germany). The AZ-dogs were given 3 weekly subcutaneous injections of $1 \mu \mathrm{g}$ GnRH-A per kilogram body weight according to the method described previously [7]. Blood samples were collected from a peripheral vein 5 weeks before and 10 weeks after the first injection of GnRH-A. Since the plasma $\mathrm{T}$ level of male dogs fluctuates diurnally $[6,16]$, blood samples were collected 3 times a day (09:00, 13:00, 17:00). Plasma T levels were determined by radioimmunoassay using the method described by DePalatis et al. [3], and the mean T level was calculated for the 3 plasma samples collected each day.

Tissue was collected twice from the right testis of each AZ- and control dog by biopsy under inhalation anesthesia 5 weeks before and 10 weeks after the first injection of GnRH-A. The tissue was stamped onto a glass slide, and the germ cells on the slide were stained with rose bengal solution $(3 \mathrm{~g}$ rose bengal, $1 \mathrm{~m} l$ formalin, and $99 \mathrm{~m} l$ distilled water ) for $15 \mathrm{~min}$ to identify sperm. The testicular tissue was homogenized, and the suspensions obtained were collected to measure SOD activity with an SOD Assay Kit (Trevigen Inc., MD, U.S.A.). A spectrophotometer was used to measure SOD activity at an absorbance of $550 \mathrm{~nm}$.

The data from the AZ- and control dogs are summarized as mean values \pm standard error (SE). Differences between means were analyzed for statistical significance by Student's $t$-test.

The mean values of the peripheral plasma $T$ level and testicular SOD activities of the AZ-dogs were significantly lower than in the control dogs $(\mathrm{P}<0.001$; Table 1$)$. The plasma T levels and testicular SOD activities of all the AZdogs increased after the GnRH-A injections, and the mean T and SOD values 10 weeks after the first injection of GnRHA were significantly higher than before the start of the GnRH-A injections $(\mathrm{P}<0.05$; Table 1$)$.

No sperm were observed on the glass slides stamped with testicular tissue collected from any of the AZ-dogs before the GnRH-A injections. However, small numbers of morphologically normal sperm were observed on the slides of one (Dog No. 2) of the 5 AZ-dogs 10 weeks after the first injection of GnRH-A. The plasma T level and testicular SOD activity values of Dog No. 2 were the highest among 
Table 1. Mean ( \pm SE) plasma T levels and testicular SOD activities of 7 control beagles and 5 azoospermic beagles, before and 10 weeks after the first injection of GnRH-A

\begin{tabular}{lrrr}
\hline & Control dogs & \multicolumn{2}{c}{ Azoospermic dogs } \\
\cline { 3 - 4 } & & \multicolumn{1}{c}{ Before } & \multicolumn{1}{c}{ After } \\
\hline $\mathrm{T}(n \mathrm{~g} / \mathrm{m} l)$ & $2.34 \pm 0.20$ & $0.83 \pm 0.14^{\mathrm{a}) * *}$ & $1.31 \pm 0.14^{\mathrm{b}) *}$ \\
$\mathrm{SOD}($ unit/g protein $)$ & $166.4 \pm 20.5$ & $73.3 \pm 7.2^{\mathrm{a}) * *}$ & $\left.109.0 \pm 13.8^{\mathrm{b}}\right) *$ \\
\hline
\end{tabular}

a)**: $\mathrm{P}<0.001$, in comparison with the value in the control dogs.

b)*: $\mathrm{P}<0.05$, in comparison with the value before GnRH-A injection.

the 5 AZ-dogs, both before and after the GnRH-A injections $(1.08 \mathrm{ng} / \mathrm{m} l$ and 86 units $/ \mathrm{g}$ protein before and $1.86 \mathrm{ng} / \mathrm{m} l$ and 169 units/g protein after).

Testicular SOD is thought to be an important antioxidant enzyme for maintaining normal spermatogenic and steroid hormone secretory function in the testis [12]. Low SOD activity in the testis induces poor spermatogenic function [18] because of an increase in ROS concentration [9]. The $\mathrm{T}$ secretion by the testes and testicular SOD activity in all of the AZ-dogs in the present study increased after the GnRHA injections. The GnRH-A injections are thought to have stimulated the LH and FSH secretory function of the anterior pituitaries of the AZ-dogs. High plasma levels of LH and FSH stimulate Leydig and Sertoli cells, respectively, in the testis. SOD has been reported that to be produced by both Leydig cells [8] and Sertoli cells [11]. The increase in SOD production in the testes of the AZ-dogs may have been directly caused by the high plasma LH and FSH levels or indirectly caused by the increase in $\mathrm{T}$ secretion by Leydig cells.

The highest values of plasma $\mathrm{T}$ and testicular SOD activity in the AZ-dogs were found in the dog whose testicular tissue, after being stamped onto a slide, revealed the presence of sperm after the GnRH-A injections (Dog No. 2). Thus, spermatogenic function in the dog appears to be maintained not only by normal $\mathrm{T}$ secretion but also by normal SOD activity in the testis.

\section{REFERENCES}

1. Alkan, I., Simsek, F., Haklar, G., Kervancioglu, E., Ozveri, H.,
Yalcin, S. and Akdas, A. 1997. J. Urol. 157: 140-143.

2. Cassani, P., Beconi, M.T. and O'Flaherty, C. 2005. Anim. Reprod. Sci. 86: 163-173.

3. DePalatis, L., Moore, J. and falvo, R.E. 1978. J. Reprod. Fertil. 52: 201-207.

4. Evans, J. and Renton, J.P. 1973. Vet. Rec. 92: 198-199.

5. Gavella, M., Lipovac, V., Vucic, M. and Rocic, B. 1996. Andrologia 28: 223-229.

6. Inaba, T., Shimizu, R. and Imori, T. 1977. Jpn. J. Anim. Reprod. 23: 63-71 (in Japanese with English summary).

7. Kawakami, E., Masaoka, Y., Hirano, T., Hori, T. and Tsutsui, T. 2005. J. Vet. Med. Sci. 67: 1249-1252.

8. Kukucka, M.A. and Misra, H.P. 1993. Mol. Cell Biochem. 126: $1-7$.

9. Manna, I., Jana, K. and Samanta, P.K. 2003. Acta Physiol. Scand. 178: 33-40.

10. Misro, M.M., Choudhury, L., Upreti, K., Gautam, D., Chaki, P., Mahajan, A.S. and Babbar, R. I2004. Int. J. Androl. 27: 8287.

11. Mruk, D.D. and Cheng, C.Y. 2000. Life Sci. 67: 133-145.

12. Mruk, D.D., Silvestrini, B., Mo, M.Y. and Cheng, C.Y. 2002. Contraception 65: 305-311.

13. Peltola, V., Huhtaniemi, I. and Ahotupa, M. 1995. Biol. Reprod. 53: 1146-1150.

14. Siciliano, L., Tarantino, P., Longobardi, F., Rago, V., De Stefano, C. and Carpino, A. 2001. J. Androl. 22: 798-803.

15. Tselkas, K., Saratsis, P., Karagianidis, A. and Samouilidis, A. 2000. Dtsh. Tierärztl. Wochenschr. 107: 67-72.

16. Tsutsui, T., Tsuji. J., Kawakami, E., Yamada, Y., Amano, T., Yamauchi, M. and Ogasa, A. 1987. Jpn. J. Vet. Sci. 49: 751755.

17. Zini, A., De Lamirande, E. and Gagnon, C. 1993. Int. J. Androl. 16: 183-188.

18. Zini, A. and Schlegel, P.N. 1997. J. Urol. 158: 659-663. 